\title{
Investigating sea piracy: crime scene challenges
}

\author{
Henri Fouche $\cdot$ Jacques Meyer
}

Received: 25 August 2011 / Accepted: 14 February 2012 / Published online: 2 March 2012

(C) The Author(s) 2012. This article is published with open access at Springerlink.com

\begin{abstract}
In April 2011, the authors assisted a task team comprised of forensic investigators and detectives to conduct a crime scene investigation on board a very large crude carrier (VLCC) at sea off Durban, South Africa. The VLCC had been held hostage by Somali pirates for 58 days prior to the investigation. This article examines the investigative challenges faced by the forensic investigators and detectives who conducted the investigation and processed forensic evidence on the VLCC which had effectively been declared a major crime scene. Qualitative data for the article was generated from questionnaires completed by the forensic investigators and the detectives who attended the crime scene and who apart from elaborating on the challenges they consider unique to processing a major maritime crime scene also include suggestions which they believe may assist in establishing best practices for dealing with and processing physical evidence at future major maritime crime scenes.
\end{abstract}

Keywords Somali pirates - Maritime crime $\cdot$ Maritime security $\cdot$ Law enforcement approach $\cdot$ Maritme crime scene investigation $\cdot$ Prosecuting pirates $\cdot$ Sea piracy

\section{Introduction}

During the last century, not much prominence was given to attacks on ships at sea. In any event nowhere near the prominence given to every incident in which an aircraft was attacked by terrorists or hijacked. Is it because the safety of seafarers are not regarded as important or is their safety just overlooked due to the routine nature of their mundane task of moving the lifeblood of the world's economies between diverse destinations on such a regular basis without fanfare?

\footnotetext{
H. Fouche $(\bowtie)$

Department of Police Practice, University of South Africa (UNISA), Pretoria, South Africa e-mail: fouchh@unisa.ac.za

J. Meyer

Interpol National Central Bureau, South African Police, Pretoria, South Africa

e-mail: MeyerJ@saps.org.za
} 
Pilfering of cargoes and opportunistic theft by dock workers has always been part of the seafaring scene and was very seldom given prominence.

Armed attacks on ships at anchor or steaming in territorial waters also lacked wide coverage, perhaps due to the low key level of violence which accompanied such attacks up until the twenty-first century.

In 2005, attacks on ships carrying food aid to Somalia prompted the United Nations Security Council (UNSC) to call on states, operating warships and aircraft in the vicinity, to assist in thwarting such attacks and culminated in UNSC resolutions ${ }^{1}$ permitting states to enter the sovereign territory of Somalia in pursuit of pirates.

The world community woke up to the realisation that attacks against ships off Somalia had reached a record level in terms of the number of incidents and the level of accompanying violence. What also stunned the world community was the seeming inability of the collective might of states and coalitions navies, drawn together by the UNSC's call for assistance, to eradicate or contain this scourge. Part of the failure to eradicate the problem arose from the seeming inability of states to initiate prosecutions against many of the captured pirates, purportedly due to lack of jurisdiction. This led to the realisation that the key to the successful prosecution of suspected pirates lies in adopting a law enforcement approach, in which an investigative phase is included. It is during this phase that the foundation is provided for a criminal case and usually determines whether the case can be taken to court once the suspected perpetrator has been arrested. The urgency to adopt a robust law enforcement approach which will lead to the successful prosecution of apprehended suspected pirates is underlined by a report, issued by Lang (2011:21), special advisor to the secretary-general of the United Nations on legal issues related to piracy off the coast of Somalia, in which it is reported that as of May 2010, more than $90 \%$ of the pirates captured have not been prosecuted. The national police forces of states are responsible for preparing the criminal case for court, whether their members took the initial statements or collected the evidence on board the attacked vessel or not. There will thus have to be a great deal of transnational coordination between police forces to secure the presence of witnesses for the trial and to ensure that the chain of custody of evidence is maintained, particularly where evidence is transferred between ships or aircraft, so as to ensure that the evidence presented in court is admissible. Worldwide, 193 national police forces are members of the International policing organisation (Interpol). The authors believe that Interpol, which has the largest membership of police forces worldwide, would be the international organisation best suited to coordinate the investigation of piracy cases by providing the necessary communication and liaison between national police forces for the preparation for a trial which would include, amongst other, the securing of the presence of witnesses from other countries. In December 2010, the European Union (EU) council adopted a decision $^{2}$ which recognises the key role played by Interpol in providing the link between military intervention and the investigation and prosecution of pirates. Interpol's history in regard to combating maritime piracy is now briefly discussed.

\footnotetext{
${ }^{1}$ UNSC resolutions 1816 and 1851 (2008)

${ }^{2}$ EU Council Decision 2010/766/CFSP: 7 December 2010. Available at www.interpol.int PR107/2010/ News \& Media releases
} 


\section{The role of Interpol in combating sea piracy}

In 1985, Interpol adopted a resolution ${ }^{3}$ in which it undertook to deal with maritime piracy as part of a specialised group within the then Police Division to co-ordinate and enhance co-operation in combating international terrorism. The anti-terrorism branch or TE branch as it was commonly known began operating in 1987 and dealt with matters relating to terrorism, firearms and explosives, attacks and threats against civil aviation, maritime piracy and weapons of mass destruction, and for a number of years Interpol's website indicated that maritime piracy was dealt with by the antiterrorism branch. Various co-operation agreements with role players in the maritime sector followed. In 2001, Interpol hosted the first international conference of offenses committed at sea. It was at this conference that a recommendation was made to the general secretariat to establish a project in order to centralise the information on piracy and other serious related crimes committed at sea. This was the start of Project BADA which was to become Interpol's main vehicle in the fight against piracy (Interpol 2009: 2).

Yet as late as 2005 Interpol had no operational, concrete activities against piracy. During the previous year (2004), Interpol's Project BADA database had only 30 incidents on record compared to the 329 incidents reported and analysed by the International Chamber of Commerce's (ICC) International Maritime Bureau (IMB) piracy reporting centre (Interpol 2009:2).

Clearly as the problem of piracy intensified, particularly in the Horn of Africa region, it became apparent that Interpol, as an international policing agency, would need to play a greater role in what was a transnational crime with rapidly developing links to organised crime.

In 2008, in response to UNSC resolution 1816, a hastily gathered task force of warships from different alliances and states soon began apprehending suspected pirates. Due to the lack of political motivation or legislation, many of the arrested pirates were subsequently released without being prosecuted. This led to the realisation that the successful prosecution of pirates would require a law enforcement approach in which the investigations of the pirate attacks are led by law enforcement officers of states national police forces. In November 2008, at an International Symposium on maritime security and crime held at the World Maritime University, Malmo, a call was made for a law enforcement approach to be adopted and applied by regional task teams to deal with the investigation and prosecution of suspected Somali pirates apprehended at sea (Fouche 2010). This approach was endorsed by the secretary general of Interpol, Mr Ronald Noble, in May 2009 when he proposed the creation of an investigative task force based in the region of the Horn of Africa with the aim of providing the link between military interventions that resulted in the arrest of suspected pirates and their subsequent prosecution (Interpol 2009). This was followed up by a commitment from Interpol to develop police and judicial investigative and prosecution capabilities on a regional level. ${ }^{4}$ Between 2009 and 2011, Interpol began building a database of fingerprints, photographs and DNA of suspects known to be involved in piracy. During this period, lobbying behind the scenes by

\footnotetext{
${ }^{3} \mathrm{AGM} / 54 / \mathrm{RES} / 1$ (Washington DC 1985)

${ }^{4}$ Interpol fact sheet COM/FS/2010-12/DCO-03 available at www.interpol.int
} 
members of Interpol's General Secretariat (IPSG) led to two UN Security Council resolutions, ${ }^{5}$ urging member states to co-operate with Interpol to secure successful prosecutions, being adopted unanimously by the UNSC within a period of 6 months. Key to the implementation of these resolutions is the importance of collecting evidence with guidance from Interpol. In 2011, Interpol formed an Incident response team to assist national police forces with the evidence collection at maritime crime scenes. To provide assistance with preserving the integrity of the evidence left behind at the crime scene, Interpol also developed a Maritime piracy task force which is augmented by a Command and Co-ordination centre which supports any of the 193 member countries with advice on the recommended best practices and protocols for preserving evidence or other physical clues in the pursuit of an investigation of an incident. ${ }^{6}$

\section{The primary purpose of an investigation}

According to Gilbert (2010: 34), criminal investigation is a logical, objective, legal inquiry involving a possible criminal activity. Gilbert points out that such an enquiry if properly conducted should be able to establish if a criminal violation as defined by a code or statute occurred, the date, time and place where the crime occurred, who the individuals were who were involved in the planning, execution and after effect of the misdemeanours, whether there are witnesses to the criminal activity present, if there is evidence of the criminal offence, the method of operation and manner in which the crime was perpetrated, and if there is an indication of guilt or innocence to aid prosecuting authorities in determining a verdict.

Clark (2004: 5-6) describes criminal investigation simply as the process followed to establish whether an act may be labelled a crime and if it is the collection of evidence to determine who is responsible and how they will be dealt with by the criminal justice system.

\section{Preliminary crime scene investigation}

Gilbert (2010: 80) describes a crime scene as a location at which a suspected criminal offence has occurred. The processing of a crime scene is one of the most important phases of the investigation. It allows the investigator to focus on the search for physical evidence. According to Gilbert, all crime scenes, to a variable degree, contain physical evidence that may be visible to the naked eyes or so small that it can only be detected by a microscope. Physical evidence comprises of all objects and material found in connection with an investigation that are instrumental in discovering the facts.

The investigator should always be able find evidence at the scene of the crime, linking the perpetrators to the crime scene and possibly connecting them to the elements of the crime. This belief is based on Locard's principle of exchange that when two objects come into contact with one another, an exchange of materials

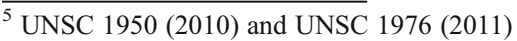

${ }^{6}$ BMP4 Best Management Practices for Protection against Somali Based Piracy (BMP4)_August 2011
} 
between the two objects occurs (Saferstein 2004: 5). According to Weston and Lushbaugh (2006: 9), Edmond Locard, founder of the Institute of Criminalistics in Lyon, France, believed that suspects introduce items of evidence into the crime scene and remove items with them on leaving the scene. This exchange of trace elements involves items such as hairs, fibres, dirt, dust, blood, body fluids, skin cells and other materials. The International Maritime Organisation (IMO) Code of Practice for the investigation of crimes of piracy and armed robbery against ships ${ }^{7}$ stresses that a detailed forensic investigation of the crime scene offers investigators the best opportunity of gleaning crucial information and evidence which may lead to the solving of the case. The Code of Practice also advises investigators to take advantage of the full range of specialist services available to them.

Pena (2000: 75-76) defines the term physical evidence as including any physical thing found at the crime scene or found at another place, but which has a direct relationship with the scene, the suspected perpetrator or the victim. He emphasises that the manner in which the physical evidence is located, collected, handled and preserved will be a determining factor in establishing the guilt or innocence of an accused.

Saferstein (2004: 62) lists various types of physical evidence commonly found on a crime scene. This includes bodily fluids like blood, semen and saliva, documents, drugs, explosives, fibres, fingerprints, hair, other impressions like tyre tracks, paint, powder residues, serial numbers, soil and minerals, tool marks and wood and other vegetative matter.

The IMO Code of Practice points out that the recovery of forensic material from a crime scene has the potential to provide evidence to identify the perpetrators. Such evidence is also required to link the suspected perpetrator to the elements of the crime.

The collection and examination of physical evidence by detectives and forensic analysts usually have two purposes namely identification and comparison.

Identification has in its purpose the determination of the physical or chemical identity of a substance with as near absolute certainty as existing analytical techniques will permit, whereas a comparison analysis subjects a suspect specimen and a reference specimen to the same tests and examination for the ultimate purpose of determining whether or not they have a common origin (Saferstein 2004: 64).

In laymen's terms, this means being able to place the suspect on the crime scene at the time the crime was committed.

\section{Processing the crime scene}

The preliminary investigator's task is concentrated on three basic elements of investigation

- Searching the crime scene

- Collecting and preserving evidence found at the crime scene

- Locating and interviewing witnesses at the crime scene

(Weston and Lushbaugh 2006: 5)

$\overline{7}$ IMO Resolution A.1025(26) adopted on 2 December 2009 
Saferstein (2004: 34-46) supports this and emphasises its importance by listing steps to be taken when processing a crime scene.

- Secure and isolate the crime scene. This is important to avoid further contamination of the crime scene and protect its integrity so that the evidence collected can be presented for prosecution later.

- Recording of the crime scene. This is done by means of photography, sketches and notes.

- The systematic search for evidence.

- The collection and packaging of physical evidence. Again, this is important so that the integrity of the evidence value is maintained.

- Maintaining the 'chain of custody'. It is important to prove the continuity of possession of a piece of evidence in court. This means in reality that every person who handled or examined the evidence must be accounted for.

Lang (2011: 23) emphasises this by stating that the collection and production of evidence in prosecutions is made difficult due to the breaking in the chain of evidence, especially when it is transferred between aircrafts or ships.

- Obtaining of reference samples, when possible.

- Submitting of the evidence to laboratories for further analysis.

\section{Evidence collection directives}

\subsection{United Nations Convention on the Law of the Sea (UNCLOS)}

Article 100 of UNCLOS imposes a duty on states to co-operate fully in the repression of piracy on the high seas.

6.2 Convention for the Suppression of Unlawful Acts against Maritime Navigation (SUA)

The States party to the SUA convention recognise the need to develop international co-operation between states in creating and implementing practical measures for the prosecution and punishment of perpetrators of unlawful acts against the safety of maritime navigation. Article 8 of the SUA convention defines the roles and responsibilities of the master of a ship, the flag state and the receiving state in delivering any person believed to have committed an offence under Article 3 of the convention to the authorities of any other state party to the convention (Article 3 includes the hijacking of a ship). Article 12 places an obligation on state parties to assist one another in connection with criminal proceedings brought in respect of offences including, amongst other, the hijacking of a ship. Such assistance includes the obtaining of evidence at their disposal necessary for the proceedings. This obligation would imply that any evidence subsequent to relevant court proceedings would need to be protected from contamination by the master of the vessel for such evidence to be admissible in court proceedings. 


\subsection{United Nations Security Council Resolutions}

UNSC 1816 (2008) and 1851 (2008) calls upon all states to co operate in the investigation and prosecution of persons responsible for acts of piracy and armed robbery off the coast of Somalia.

UNSC 1918 (2010) endorses the duty of states to cooperate in repressing acts of piracy and calls on states to consider prosecution, pointing out that the failure to prosecute Somali pirates undermines the anti-piracy efforts of the international community.

UNSC 1950 (2010) and 1976 (2011) calls on all states to co-operate in the investigation and prosecution of all persons responsible for acts of piracy and armed robbery off the coast of Somalia. The resolutions welcome the work of the International Maritime Organisation (IMO) and Interpol in providing guidance to seafarers on preserving crime scenes following acts of piracy and provide that seafarers be given the opportunity to give evidence in criminal proceedings. The resolution also underlines the importance of continuing to enhance the collection, preservation and transfer of evidence of acts of piracy to the relevant prosecuting state with guidance from Interpol. Resolution 1950 also urges states to make their citizens and vessels available for forensic investigation as appropriate at the first port of call immediately following an act of piracy or armed robbery at sea on release from captivity.

UNSC 2020 (2011) expresses grave concern at the extended range of the piracy threat into the Western Indian Ocean and adjacent sea areas and recognises the need to investigate and prosecute not only suspects captured at sea, but also persons who incite or intentionally facilitate piracy operations and includes persons who plan, organise, facilitate or finance and profit from pirate attacks.

The resolution takes cognisance of and expresses appreciation to the IMO and shipping industry for the development of guidelines, best management practices and recommendations to assist ships to prevent and suppress piracy attacks off the coast of Somalia and the Gulf of Aden.

\subsection{United Nations Security Council: report of the special advisor}

to the secretary-general on legal issues related to piracy off the coast of Somalia ${ }^{8}$

Proposal 20 of the special report reiterates that evidence must be identified and gathered if perpetrators of piracy are to be successfully prosecuted. The proposal calls for the establishment of special regional teams to investigate piracy by, amongst other, analysing the crime scene and taking fingerprints and DNA samples immediately after a hijacked vessel has been released by the pirates.

6.5 International Maritime Organisation (IMO) code of practice for the investigation of crimes of piracy and armed robbery against ships ${ }^{9}$

The purpose of the code of conduct referred to in UNSC resolution 1950 is to provide member states with guidelines to facilitate the investigation of the crimes of piracy

\footnotetext{
${ }^{8}$ UNSC S/2011/30 Annex to letter dated 24/01/2011.

${ }^{9}$ Resolution A.1025(26)
} 
and armed robbery against ships. On 23 May 2011, guidelines to be read in conjunction with resolution A.1025 (26) were issued by the IMO via MSC./Circ.1404. The guidelines reiterate that the capture, prosecution and sentencing of pirates and armed robbers is probably the most appropriate deterrent action available to governments and provides further guidelines designed to assist with statement taking from victims and the securing of the crime scene and recovery and packaging of exhibits.

\subsection{Best Management Practices for Protection against Somali Based Piracy ${ }^{10}$}

The fourth version of the Best Management Practices for Protection against Somali Based Pirates (BMP4) contains guidelines, designed and endorsed by industry, to assist ship operators and masters of ships transiting the high-risk areas. The guidelines provide advice to masters on a range of operational practices which include the possible monitoring and recording of an attack with closed circuit television (CCTV) from a less exposed position. Such recorded CCTV footage may provide useful evidence after an attack and may assist in identifying perpetrators and provide evidence in subsequent judicial proceedings. Seafarers are also encouraged to provide witness statements to law enforcement officials in order to assist with the initiation of prosecution proceedings. The company and crew are also encouraged not to taint or destroy potential evidence which may be presented to court during the trial of the perpetrators.

\subsection{Djibouti Code of Conduct (2009)}

In January 2009, the IMO convened a meeting of states in the region of the Horn of Africa. At this meeting which was held in Djibouti, a Code of Conduct concerning the repression of piracy and armed robbery against ships in the western Indian Ocean and the Gulf of Aden was agreed upon. The code, which has to date been signed by 18 states in the region, ${ }^{11}$ particularly focuses on agreement between the signatories to cooperate, in a manner consistent with international law, in the investigation, arrest and prosecution of persons who are reasonably suspected of having committed acts of piracy and armed robbery against ships.

\section{Case study}

On 10th April 2011, the Interpol General Secretariat (IPSG) requested the Interpol National Central Bureau (NCB) of the South African Police, pursuant of UNSC resolution 1950, to assist an Incident Response Team (IRT) from Lyon, France, to conduct an investigation on board a Greek flagged very large crude carrier (VLCC), the Irene SL, released from captivity after being held hostage by Somali pirates for 58 days. A task team was assembled and boarded the VLCC approximately 5 nautical miles off the port of Durban, South Africa, as the first port of call after release from captivity. The team comprised of forensic investigators, detectives and a biological

\footnotetext{
${ }^{10}$ BMP4. August 2011. Witherby Publishing Group Ltd. Edinburgh. ISBN:978 1856095051

${ }^{11} \mathrm{http}: / /$ www.imo.org/OurWork/Security/PIU/Pages/Signatory-states.aspx
} 
body fluids detection dog. The purpose of the investigation was to search for and collect evidence and exhibits and conduct interviews with the crew with a view to identifying the crimes committed and the identity of the perpetrators with a view to prosecution. The fully laden VLCC was too large to enter the port of Durban and there are no protected (safe) anchorages available along the Kwa-Zulu Natal coast. The vessel was boarded using police resources which consisted of three 7.8-m rigid hull inflatable boats and a $20-\mathrm{m}$ police boat. ${ }^{12}$ The weather conditions were adverse and the first attempted boarding at night had to be partially aborted because of severe damage to one of the rigid hull inflatable boats and loss of the equipment being transported therein. The investigation was completed in $24 \mathrm{~h}$, and several bags of physical evidence were collected and removed from the vessel. This included DNA from bodily fluids, fingerprints, documents and ammunition.

\section{Conceptual demarcation}

\subsection{Forensic specialists}

Forensic specialists are described by Berg and Horgan (1998:40) as persons specifically trained to collect evidence and to conduct scientific tests on and assess various types of physical evidence. Specific tasks to be performed by the forensic specialist are described by Berg and Horgan as the recognition and discovery of relevant physical evidence, determining whether such evidence can be tested or compared in a forensic crime laboratory, the handling, packaging and labelling of such evidence and ensuring that the chain of custody is maintained, recording how, where and by whom the evidence was located, transportation of the evidence to the laboratory and maintaining the integrity of the chain of custody, to the laboratory and from the laboratory to the court for the criminal proceeding at which the investigator will also have to present evidence. To be able to effectively collect evidence at the crime scene the investigator needs to know what crimes are suspected to have been committed and to have knowledge of the elements of those crimes.

For the purpose of this article, a forensic investigator can be regarded as the person responsible for identifying and collecting forensic evidence comprising trace elements at the crime scene.

\subsection{Detective}

Charles Dickens introduced the word detective in a novel Bleak House in 1853. This was the first time that the word detective, which universally became the accepted designation for referring to an investigative law enforcement officer, appeared in print (Gilbert 2010: 8).For the purpose of this article, detectives are regarded as the persons who were responsible for identifying potential evidence for collection by the forensic investigators on the scene and for taking statements from victims as well as fingerprints of victims for elimination purposes.

\footnotetext{
12 The South African Air force helicopter was not available to assist with the operation
} 


\section{Profile of responders}

The six participants responsible for collecting forensic evidence (forensic investigators) consisted of three commissioned officers and three non-commissioned officers. The commissioned officers' service in law enforcement ranged between 17 and 32 years of which between 8 and 25 years were as forensic investigators. The non-commissioned officers' service in law enforcement ranged between 6 and 20 years of which between 2 and 10 years were as forensic investigators. All six of the participants indicated that they had previously processed physical evidence at major crime scenes and all had at some stage been in charge of processing evidence at a major crime scene. For all six participants, the forensic investigation on the VLCC was the first time that they had processed a major maritime crime scene.

The 10 participants responsible for taking statements and fingerprints (detectives) consisted of three commissioned officers and seven non-commissioned officers. The commissioned officers' service in law enforcement ranged between 23 and 40 years of which between 19 and 27 years were as detectives. The non-commissioned officers' service in law enforcement ranged between 15 and 30 years of which between 7 and 29 years were as detectives. All 10 of the participants indicated that they had previously attended major crime scenes and nine of the detectives had at some stage been in charge of investigating a major crime scene. For all 10 participants, the forensic investigation on the VLCC was the first time that they had processed a major maritime crime scene. The overall commander of the operation was among this group of participants.

\section{Methodology}

For the purpose of data collection, the authors employed a self-administered qualitative questionnaire for the six forensic investigators and 10 detectives as a way of getting information directly from the participants in each of the two categories. This method is based on an established questionnaire - a set of questions with fixed wording and sequence of presentation (Bless and Higson-Smith 1995: 107) and was completed by each of the participants. The questionnaire consisted of openended questions relating to the challenges encountered by the participants and allowed them to freely relate their experiences and perceptions during the investigation, the differences they experienced between processing a major terrestrial crime scene and a major maritime crime scene, the challenges they encountered at the major maritime crime scene and the challenges they considered to be unique to processing such a crime scene. Provision was also made for comments by the participants regarding what they believe may assist in establishing best practices for dealing with future major maritime crime scenes. The responses from the two categories (forensic investigators and detectives) were grouped thematically, and reported on in the findings, to allow for comparison between the experiences of the forensic investigators and the detectives participating in the same investigation of a major crime scene in a maritime environment, taking into account that their experience could assist in establishing best practices for dealing worldwide with major maritime crime scenes. 


\section{Findings}

In response to a question as to how in their experience processing physical evidence at a major maritime crime scene differed from processing physical evidence at a major terrestrial crime scene, the six participants (forensic investigators) responsible for the processing of physical evidence at the crime scene indicated that:

- Crime scene contamination by the victims and other role players responding to the incident earlier resulted in evidence being lost (first responders from a warship who boarded the hijacked VLCC, after its release, destroyed some evidence, including the aluminium ladders and grappling hooks used by the perpetrators of the hijacking to board the vessel, by throwing them overboard).

- Access to equipment and the availability thereof was hampered due to the location of the crime scene at sea.

- The humidity was much higher at sea level and equipment and substances packed by the team in Pretoria, situated at 3,400 $\mathrm{m}$ above sea level, was in some instances not ideal.

- Team members' performance was not optimal due to some instances of motion sickness. This had not been anticipated beforehand.

- The environmental conditions were bad and there was no protection on deck from conditions such as strong wind which blew pieces of evidence overboard as soon as they were disturbed. This was exacerbated by the continuous movement (rolling) of the vessel.

- Communication between team members was hampered due to poor cell phone signal strength off the coast and there were no handheld radios available for communication between team members.

- The vessel's crew members had to stay aboard and could not be removed out of the crime scene during processing and interviews as would normally be the procedure at a terrestrial crime scene.

- Although the crime scene had been occupied for a long period due to the hostage taking, much of the incriminating evidence had been discarded by simply having been thrown overboard.

In response to the same question, the 10 detectives' responses indicated that the differences that they had experienced were:

- There are no standing operating procedures (SOP) in place for such events. This lack of SOP's resulted in a lack of or poor communication and misunderstanding between the owners, ships agents, law enforcement, Interpol and first responders who had already boarded the vessel and not adhered to crime scene management principles.

- The establishment of a command centre at sea was more challenging as it had to be established on the vessel which effectively was the crime scene.

- The control of the scene, however, was easier as there were no crowds to control.

- It was more difficult to access the crime scene and to get the investigators and their equipment aboard the vessel. 
- Difficulty in cordoning off many different scenes over a large area. Far more planning and control had to be exercised in regard to the crime scene.

- Contamination at the scene is maximised because space and movement is limited at a maritime crime scene.

- A limited time window to process the crime scene which is already contaminated.

- The need to be self-contained once aboard vessel/crime scene.

The forensic investigators experienced the following challenges while processing evidence at the maritime crime scene:

- The scene was already contaminated resulting in a huge loss of possible evidence (up to $80 \%$ )

- Moisture had affected and degraded some evidence such as fingerprints and DNA particularly on the decks where it had come into contact with seawater. Difficulty was experienced in accessing the scene at sea.

- Limited space was available to transport equipment to the scene.

- Time constraints could have resulted in evidence being overlooked.

- Marking the position of exhibits for capturing was difficult due to the continuous motion of the vessel.

- Motion sickness affected the performance of team members.

- The equipment taken aboard was more suitable for processing terrestrial scenes (cameras and reagents were affected by moisture and weather changes. Reagents not properly packed were affected by moisture due to humidity. Lenses became covered in moisture and no lens cleaning tissues were available.)

- Processing was interrupted and had to be stopped when the vessel was affected by rough weather.

- Time for processing was much too short and members had to rush processing. In many cases, collection was limited to merely 'bagging and tagging' and documentation.

- Large quantities of evidence could not be processed and had to be left behind (equipment, bedding, clothing, empty containers, etc. dumped by perpetrators) due to lack of time and space on the police boats.

Challenges experienced by the detectives in response to the same question were:

- Owners need to be first aboard to talk to the crew which resulted in further contamination.

- The need to clean the vessel. The mess left behind by the perpetrators after 58 days of occupation had to be cleaned for health and safety reasons and so that the offices and spaces which had been occupied could be utilised to continue the voyage. A team was sent aboard the vessel in Durban to replace all the mattresses and further clean up the debris of the occupation. On the one hand, these necessary actions hampered the investigation by removing potential evidence, and on the other hand the presence of the cleaning team further contaminating the crime scene which comprised the entire vessel.

- Non-adherence to crime scene management principles by military personnel who boarded the vessel after its release. Exhibits were dumped in the ocean by the military first responders. 
- The crime scene was 2 to 3 months old and there was a challenge to get evidence after the vessel had been cleaned.

- Availability of witnesses due to handover to new crew and witnesses having to conduct necessary technical tests to the vessel. Very limited time period in which to take statements. The victims were traumatised and could barely speak English. The time restraints before the commencement of the investigation and uncertainty/ lack of information concerning the nationalities of the crew resulted in interpreters not being available to interpret during statement taking. The statements were thus of necessity taken down in English, without the assistance of interpreters.

- Insufficient background information as to events or suspects was available beforehand. Statements taken by first responders were not available.

- Disorientation on board the vessel (crime scene) due to unfamiliar surroundings.

The forensic investigators considered the following challenges to be unique to processing a major maritime crime scene

- The difficulty to take control, secure and protect the scene.

- The limited time available to process and document the scene (due to having to avoid costly delays to the vessel's owners).

- Communication between team members and victims due to language barriers.

- Limits on the use of equipment such as flash photography, electrostatic dust lifter and other specialised equipment due to safety regulations on board the vessel.

- Time exposures during photography were difficult .The vessel was stopped and was lying head to wind beam on to the sea and rolling, making the platform for the time exposure camera unstable and causing blurring.

- Maintenance of used equipment such as recharging of batteries was difficult and availability of power with compatible current ( $220 \mathrm{~V}$ in this instance) a challenge.

- Team members had not worked together before and did not know each other's abilities and skills which could have resulted in instructions not being carried out.

- Due to time restraints, evidence collection needs to be selective to achieve outcome-based processing, resulting in some evidence not being able to be processed. For this to be successful, there needs to be continuous communication between members of the task team.

- The fact that the vessel itself is the crime scene and anything beyond the vessel is lost as physical evidence unless that physical evidence can be linked back to the vessel.

- The perimeter of the processing area cannot be extended.

- Cameras are not allowed in some areas for safety reasons. The vessel was fully laden which resulted in vapours in the atmosphere presenting a fire hazard preventing the use of cameras utilising batteries and flashlights. To overcome this, a spheron scan $360^{\circ} \times 180^{\circ}$ capturing device can be utilised. This and similar devices can operate in low lighting conditions and can be operated without an additional light source.

- Lack of information about place of certain occurrences and the lack of preservation of evidence therein.

- Totally different terrain to work in. Everything is steel.

- Changing weather conditions make work difficult. 
In response to the same question, the detectives found the following challenges to be unique to investigating a major maritime crime scene:

- Planning and processing of the crime scene. Planning normally takes place at the scene. In this instance, planning for every possible contingency had to be done before arrival at the crime scene, that is, the vessel.

- Gaining access to and controlling the crime scene at sea.

- The crime scene was already contaminated and there is a possibility of further contamination due to lack of manoeuvrability in confined spaces and amount of equipment needed to be self-sufficient at the scene.

- Jurisdiction and legality. Misunderstanding of the role, competencies and jurisdiction of the task team by ship ownership and management. The master of the vessel is effectively in control of the crime scene and in a position to dictate to the task team.

- The size of the team necessary to conduct the investigation effectively and efficiently is limited and dictated to by logistical and safety factors and confined by time constraints.

- Unfamiliar modus operandi of the suspects and the number of suspects involved. $^{13}$

- Terminology used to refer to persons, places and procedures on board the vessel.

- The size of the crime scene.

The forensic investigators believed that the following may assist in establishing best practices for dealing with processing of physical evidence at future major maritime crime scenes:

- Team members should be provided with timely information of the extraordinary nature of the crime scene for example whether the vessel was used as a mother ship and the nature of the crimes that can be expected to be encountered at the scene. This is necessary to establish the desired outcomes which are not only to identify and link the perpetrators to the crime scene by way of trace elements, but to connect them to the elements of the crimes committed.

- Equipment must be packaged in protective packaging and must be easily identified and readily accessible.

- Proper communication and lighting equipment must be available.

- Standard operating procedures (SOP) must be in place.

- Team members should know one another. Training should be given to task team members and regular exercises held.

- Team members should be issued with correct personal protective equipment.

- Team members must be aware of their rights and powers at the crime scene (for example if necessary can a door be broken down)

- Effective processing can only be done if there is sufficient time at the disposal of the processing team.

\footnotetext{
$\overline{13}$ The use of hijacked vessels as 'mother ships', the use of the automatic identification system (AIS) and satellite telephones, the boarding methods and subsequent methods used to gain control of the vessel.
} 
In response to the same question, the detectives believed that the following may assist in establishing future best practices:

- International SOP should be established for dealing with future incidents.

- Military personnel on warships need to be sensitised regarding crime scene management principles and securing and safeguarding of physical evidence such as DNA, fingerprints and equipment used by pirates.

- A permanent task team consisting of investigators and experts from law enforcement as well as the prosecuting authority needs to be established to react on an ad hoc basis. The investigation should be court driven from the onset with a view to securing convictions of perpetrators after properly establishing the areas of jurisdiction.

- Team members should be provided with suitable attire.

- A designated port and area within the port should be identified to process vessels declared crime scenes.

- Task team should be self-reliant in terms of logistics such as food and water.

- Ships crews need to be thoroughly briefed in advance how to deal with evidence identification and protection after being released.

- The team leader should have access to sufficient readily available funds to deal with contingencies which may arise such as the need to hire a helicopter or civilian boats to assist with transporting large amounts of evidence.

- Prior contact with probable prosecuting authorities to ensure successful prosecution in instances where legal proceedings need to be instituted in countries other than those where the investigators are based.

\section{Observations and recommendations by authors}

The authors of this article make the following observations and recommendations:

- The principles of investigation remain the same for a maritime crime scene as for a terrestrial scene. The difference in domain and the resultant challenges inherent to the maritime domain, however, need to be taken into account by detectives and forensic investigators in their preparation for and processing of the maritime crime scene.

- Equipment used by investigators should be carefully chosen, keeping in mind the environmental challenges that exist. This includes lighter equipment that is waterproof, or waterproof containers that will be able to protect expensive equipment.

- It would be advisable to use the same group of investigators for this type of investigation. This would create a speciality team that would be prepared for the challenges typically associated with a maritime crime scene. A permanent maritime crime scene management team, consisting of specialists in various forensic and investigative fields, is therefore advisable. The team should also have a database available with the details of interpreters who can be called up at short notice. It would also be useful to have data on medical doctors and trauma councillors available for call up at short notice. 
- A Troika approach using the investigator, prosecutor from the flag state/ prosecuting country and intelligence in a combined effort is also recommended when conducting the investigation of the crime scene of maritime piracy. The IMO Code of Practice points out that investigators should be aware that the laws governing offences committed at sea may allow for legal proceedings in countries other than those where the investigation was conducted. It is also recommended that it be made mandatory for ship owners to lay a criminal charge in the flag state against the perpetrators to enable Interpol to issue red notices for arrest and extradition to the prosecuting state(for an Interpol red notice to be issued, there needs to be a valid arrest warrant in the country requesting extradition).

- Resources in the form of equipment and finances should be permanently available for this team. Resources from regional or flag states could be pooled to ensure that there is always a team knowledgeable in the maritime environment ready at hand to conduct such investigations.

- A directive or protocol for the identification and protection of evidence on maritime crime scenes should be developed and distributed to all role players involved.

- Guidelines need to be established for investigators to follow when dealing with traumatised victims. The IMO Code of Practice for the investigation of crimes of piracy and armed robbery against ships points out that investigators should be aware that the witnesses they are dealing with are likely to be exceptionally distressed, particularly if they have been subjected to violence, been held hostage for long periods and been in fear of death. The code emphasises that investigators should take cognisance of such factors and consequently the need to deal emphatically and patiently with such witnesses if they are to elicit all the relevant facts during interviewing.

- Better communication with the shipping industry regarding the protection of a crime scene is of vital importance to ensure the integrity and evidential value in court of physical evidence collected on a maritime crime scene.

- Training with regard to the handling of a crime scene and evidence should also be given to other armed forces and navies, as these forces are often the first responders on such vessels after they have been released by pirates.

- Adding to this, better communication between law enforcement and the military should be established. (In the case of the Irene, investigators only became aware of the actions of military first responders on the vessel after its release, when interviewing the crew.)

- Interpol's current resources should be extended beyond ground-level law enforcement to military personnel and ships so that they can have access to its fingerprints, DNA, nominal and pirate photo album databases and services.

- It would be advisable to have the option of air transport available for the team to board the vessel, prior to it docking at a harbour, thereby avoiding further contamination of the crime scene by third parties. 


\section{Conclusions}

Successful prosecution of perpetrators of piracy requires detailed evidence collection according to pre-planned procedures. There is an urgent need for specially trained evidence collection teams, knowledgeable in the maritime domain and with all the necessary equipment including protective clothing, adapted if necessary for the environment, to be available to conduct forensic investigations on ships which have been released after being hijacked by Somali pirates. It would be advantageous to have a person from the potential prosecuting authority as a member of the team. Such investigations should be conducted in a port or sheltered anchorage. The ship would need to be available for a sufficient amount of time to allow for a thorough investigation. The teams would need to hold exercises regularly to provide team members the opportunity of working together, familiarising themselves with the layout of various types of vessels, testing the suitability and availability of equipment and getting to know each other's abilities and skills. Communication before, during and after the operation is crucial. Before the operation between the owners, ships agents, the master of the ship and the team leader (as much information as possible should be made available regarding the alleged offences, the method of operation of the perpetrators, the composition of the crew in order to arrange interpreters, the estimated time of arrival, and all information which would assist with the investigation), during the operation between team members themselves and with the ships management and after the operation between the parties responsible for the preparation of the case for prosecution and the prosecuting authority of the state in which the trial is to take place(with regard to availability of witnesses and evidence and admissibility of evidence). Crime scene management principles in relation to the protection of possible evidence needs to be observed by first responders from military units as well as wherever possible by the master and crew of the hijacked ship. Ships masters and crews need to be conversant with the best management practices, provided by the shipping industry and international organisations such as the International Maritime Organisation (IMO) and International Chamber of Commerce (ICC) International Maritime Bureau (IMB), relating to evidence protection.

Every effort should be made, by all role players across the globe, to assist in procuring the successful prosecution of the perpetrators of the crime of piracy.

Open Access This article is distributed under the terms of the Creative Commons Attribution License which permits any use, distribution, and reproduction in any medium, provided the original author(s) and the source are credited.

\section{References}

Berg BL, Horgan JH (1998) Criminal investigation (3rd ed.). Glencoe/McGraw-Hill, Westerville, USA

Bless CA, Higson-Smith C (1995) Fundamentals of social research methods: an African perspective, 2nd edn. Juta, Kenwyn

Clark C (2004) Bevan \& Lidstone's the investigation of crime, 3rd edn. LexisNexis, UK 
Djibouti Code of Conduct (2009) The Djibouti Code of Conduct (Resolution 1). [Online]. Available from: http://www.imo.org/OurWork/Security/PIU/Pages/DCoC.aspx [accessed on 2011/08/19.

Fouche (2010) The manifestation and challenges of combating piracy in Africa. In: Maximo Q. Mejia Jr. (ed) Maritime security and crime. WMU, Malmo, pp. 147-157. [ISBN 978-91-977254-3-9]

Gilbert JN (2010) Criminal investigation (8th ed.). Pearson Education, Upper Saddle River

Interpol (2009) May 29. Law enforcement is "missing link" in fight against maritime piracy, Interpol chief tells G8 meeting. Interpol media release. Retrieved November 10, 2009, from www.interpol.int

Lang (2011) Report of the Special Advisor to the Secretary-General on Legal Issues Related to Piracy off the Coast of Somalia. Annex to UNSC S/2011/30 dated 25 January.

Pena MS (2000) Practical criminal investigation (5th ed.). Wadsworth/Thomson Learning, Belmont, USA

Saferstein R (2004) Criminalistics: an introduction to forensic science (8th ed.). Pearson/Prentice Hall, Upper Saddle River

Weston PB, Lushbaugh CA (2006) Criminal investigation: basic perspectives (10th ed.). Pearson/Prentice Hall, Upper Saddle River 